\title{
SPECIAL PRE-TRIAL INVESTIGATION OF CRIMINAL OFFENSES: CHANGES CONTINUE
}

\author{
Oleksandr Vereshchak \\ Postgraduate Student at the Department of Criminal Procedure, \\ National Academy of Internal Affairs, Ukraine \\ e-mail: Oleksandr.vereshchak.int@gmail.com, orcid.org/0000-0003-3895-7337
}

\section{Summary}

In this article author explores the law regulation of the institute of the special pre-trial investigation of criminal offenses considering the changes. The light is shed on the role of the public prosecutor in the context of motion trial during the special pre-trial investigation. The issue of introducing changes to the Chapter $24^{1}$ of the Criminal Procedure Code of Ukraine is considered. The grounds for conducting the special pre-trial investigation or special court proceeding are analyzed. The legislative consolidation of the possibility of declaring international and/or interstate searching of a person is covered. The duty of the investigator (or the public prosecutor) regarding the proof of the fact that the suspect is hiding from the investigating authority aiming to evade the criminal liability (i. e. the suspected person has to know that there is a criminal case against him/her and he/she is notified of suspicion; however, he/she is hiding aiming to evade the criminal liability) is defined. Therefore, the investigating judge is obliged to take into consideration availability of sufficient evidence for suspicion of a person, towards which the motion for conducting of a special pre-trial investigation is filed. The trial of the motions for conducting of a special pre-trial investigation, special court proceeding of the offenses, mentioned in the Part 2 Art. $297^{1}$ of the Criminal Procedure Code of Ukraine is conducted by the court in according to the rules of jurisdiction, defined in the Art. 32 of the Criminal Procedure Code of Ukraine.

Keywords: international searching, notification of suspicion, motion for special pre-trial investigation, special pre-trial investigation, simplified proceedings, trial in absentia, participants of criminal proceeding, procedural documents.

DOI: https://doi.org/10.23856/4530

\section{Introduction}

The issue of ensuring the inevitability of criminal prosecution for a criminal offense has always been one of the key components of criminal policy in our country.

With the Law of Ukraine "On Amendments to the Criminal and Criminal Procedure Codes of Ukraine on the inevitability of punishment for certain crimes against the foundations of national security, public safety and corruption crimes" № 1689-VII of 07.10.2014 the Criminal Procedure Code of Ukraine was supplemented with a new Chapter $24^{1}$ "Features of a special pre-trial investigation of criminal offenses", which contains five articles (Articles $297^{1}-297^{5}$ of the Criminal Procedure Code of Ukraine).

Its effective implementation in relation to persons who commit criminal offenses under Part 2 of Art. $297^{1}$ of the Criminal Procedure Code of Ukraine, is of great importance for today's society because of its extremely negative attitude to these phenomena. One of the procedural means of ensuring the inevitability of punishment for a criminal offense is the use, in cases 
where a person is hiding from the pre-trial investigation and court, of the procedures of criminal proceedings in absentia.

The possibility of a special pre-trial investigation is also envisaged in Part 5 of Art. 139 of the Criminal Procedure Code of Ukraine, according to which evasion the appearing at the summons of an investigator, prosecutor or court summons of an investigating judge, court (failure to appear at the summons without good reason more than twice) by a suspect/accused person and declaring him/her in interstate and/or international searching are the grounds to conduct a special pre-trial investigation or special court proceedings.

Thus, the relevance of the topic is due to the fact that one of the priority tasks of criminal proceedings is to provide legal mechanisms that determine the implementation of the principle of inevitability of liability for a criminal offense. An important component of filling this principle with specific content is the introduction of this institution by the domestic legislator. Its implementation in the legal field of Ukraine creates the preconditions for prosecuting persons who evade investigating authority or court and is designed to increase the effectiveness of protection of public interests of the state. At the same time, it should be noted that the introduction of this institute requires a detailed study and rethinking of some of its aspects.

The purpose of the study is to summarize the current criminal procedure legislation, the practice of its application and special literature, to highlight the main issues of special pre-trial investigation and trial within criminal proceedings.

Methodologically, the study is based on the dialectical method of cognition, on the general methods of analysis and synthesis, induction and deduction, on identifying analogies and comparisons, on a systematic approach in the analysis of legal relations and legal documents, on formal-logical and comparative-legal methods of interpreting law, both on the theoretical and empirical levels.

\section{Main material}

The exploring of certain problematic issues related to special pre-trial investigation and trial in absentia is relevant and necessary, as this institution can be considered new and in need of improvement, borrowing practical experience from other countries. The scientific works of Iu. Azarov, D. Alekseeva-Protsiuk, A. Barabash, V. Drozd, O. Kuchynska, L. Loboyko, V. Maliarenko, M. Markusha, M. Mykheienko, and O. Nahorniuk-Danyliuk, V. Nor, R. Piestsov, P. Pylypchuk, D. Pysmennyy, S. Shmalenia and others are devoted to separate issues concerning the special pre-trial investigation.

A special pre-trial investigation (in absentia) is conducted against one or more suspects in accordance with the general rules of pre-trial investigation provided by the Criminal Procedure Code, subject to the provisions of Chapter $24^{1}$.

The special pre-trial investigation is carried out on the basis of the decision of the investigating judge in criminal proceedings concerning the crimes provided by Articles 109, 110, $110^{2}, 111,112,113,114,114^{1}, 115,116,118$, Part 2 of Art. 121, Part 2 of Art. 127, Parts 2-3 Art. 146, Articles 146 1 , 147, Parts 2-5 of Art. 191 (in case of abuse by an official of his official position), Articles 209, 255-258, 258 ${ }^{1}, 258^{2}, 258^{3}, 258^{4}, 258^{5}, 348,364,364^{1}, 365,365^{2}, 368$, $368^{2}, 368^{3}, 368^{4}, 369,369^{2}, 370,379,400,408,436,436^{1}, 437-447$ of the Criminal Code of Ukraine, concerning the suspect, except the minor, who hides from of investigating authorities and court in the temporarily occupied territory of Ukraine, in the territory of the state, recognized by the Verkhovna Rada of Ukraine (the Parliament) as an aggressor state, in order to evade criminal liability and/or declared internationally wanted. 
Special pre-trial investigation of other crimes is not allowed, except when the crimes were committed by persons hiding from the investigating authorities and court in the temporarily occupied territory of Ukraine, in the territory recognized by the Verkhovna Rada of Ukraine (the Parliament) as an aggressor state, in order to evade criminal liability and/or are internationally wanted and are being investigated in the same criminal proceedings as the offenses set forth above, and the release of materials concerning them may adversely affect the completeness of the pre-trial investigation and trial.

It is pointful to note that the interstate searching is conducted in the manner prescribed by the Agreement of the Member States of the Commonwealth of Independent States on the interstate searching of persons from 10.12.2010. The international searching of persons is regulated in Ukraine by a joint Order of the Ministry of Internal Affairs of Ukraine, the Office of the Prosecutor General of Ukraine, the National Anti-Corruption Bureau of Ukraine, the Security Service of Ukraine, the State Bureau of Investigation of Ukraine, the Ministry of Finance of Ukraine, the Ministry of Justice of Ukraine dated August 17, 2020 № 613/380/93/228/414/510/2801/5 "On approval of the Instruction on the procedure for use by law enforcement agencies of Ukraine of the information system of the International Criminal Police Organization - Interpol", registered at the Ministry of Justice of Ukraine on September 4, 2020 for № 849/35132.

If several persons are notified of a suspicion in criminal proceedings, the investigator, prosecutor has the right to apply to the investigating judge with a motion to conduct a special pre-trial investigation only in respect of those suspects in respect of whom there are grounds under Part 2 of Art. $297^{1}$ of the Criminal Procedure Code of Ukraine, and in respect of other suspects further pre-trial investigation in the same criminal proceedings will be carried out in accordance with the general rules provided by the Criminal Procedure Code of Ukraine.

Thus, a special pre-trial investigation is a differentiated procedure for conducting a pretrial investigation of crimes, which is applied in cases of evasion of a suspect criminal liability by concealment from the investigation authority and court, aimed at providing evidence at the stage of pre-trial investigation in criminal proceedings, taking into account the standards of fair justice.

The fact that special proceedings are an independent procedural form is evidenced by a number of features that at the general theoretical level were once defined by V. Trofymenko: a) a special procedure; $b$ ) its clear legal regulation; c) the orientation of the procedure, prescribed by law, to solve problems of a particular area of procedural activity (Trofymenko, 2012: 203).

Based on the provisions of Ch. $24^{1}$ of the Criminal Procedure Code of Ukraine, a special pre-trial investigation is carried out on the basis of the decision of the investigating judge on the basis of the relevant motion of the prosecution.

We consider it necessary to determine the exclusive role of the prosecutor at the stage of drafting and sending the motion, which is as follows: the prosecutor decides on the motion to be applied for consideration by the investigating judge, determines the limits of its consideration, supports the motion before the investigating judge and supervises the legality of the execution of the decision made by the investigating judge on this issue (Lapkin, 2013).

We agree with the opinion of A. Lapkin that the role of the prosecutor in initiating a special pre-trial investigation is manifested primarily in the fact that he is an entity authorized to appeal to the investigating judge with a motion to conduct such an investigation. Along with the prosecutor, the investigator has the same right, but the latter exercises this in agreement with the prosecutor. Thus, the prosecutor initiates the issue in two forms: 1) by personally appealing to the investigating judge with a motion to conduct a special pre-trial investigation; 
2) by approving the motion filed by the investigator. In any case, the described issue can be initiated only at the will of the prosecutor (Lapkin, 2018).

Proper procedural registration of the initiation of a special pre-trial investigation envisages preparation and submission for consideration by the investigating judge of the relevant motion, the requirements for which are provided in Art. $297^{2}$ of the Criminal Procedure Code of Ukraine. In this motion, the prosecutor, the investigator must set out the grounds for a special pre-trial investigation, as well as the confirming circumstances.

When the investigating judge is deciding on the conduct of a special pre-trial investigation, the prosecutor is obliged to support the motion and assist in clarifying the circumstances of the criminal proceedings, hearing any witnesses or examining any materials relevant to the issue of special pre-trial investigation, as well as to prove to the investigating judge the existence of sufficient evidence to suspect the person in respect of whom the motion was filed, of committing a criminal offense (Part 2 of Art. $297^{2}$ of the Criminal Procedure Code of Ukraine).

Conducting of criminal proceedings under the rules in absentia imposes additional obligations on the prosecutor to protect the rights of the suspect, because according to Part 2 of Art. 7 of the Criminal Procedure Code of Ukraine, he is obliged to use all opportunities provided by the law to respect the rights of the suspect (including rights to protection, access to justice, secrecy of communication, non-interference in private life) in the event of criminal proceedings in the absence of the suspect. The prosecutor should pay special attention to ensuring that the suspect is properly informed about the progress of the special pre-trial investigation.

Based on the analysis of Art. $297^{5}$ of the Criminal Procedure Code of Ukraine, the following mandatory forms of informing can be distinguished: 1) sending subpoenas to the suspect at the last known place of his/her residence or stay; 2) publication of these subpoenas in the mass media of the national sphere of distribution and on the official websites of the authorities conducting pre-trial investigation; 3 ) sending to the defense counsel copies of procedural documents that are to be handed to the suspect.

The President of Ukraine signed the Law "On Amendments to the Criminal Procedure Code of Ukraine to improve certain provisions in connection with a special pre-trial investigation” № 1422-IX, which was adopted by the Verkhovna Rada of Ukraine on April 27, 2021.

This document is designed to ensure the inevitability of punishment of citizens who have committed a criminal offense and are hiding from the investigation in other countries or in the temporarily occupied territories of Ukraine.

According to Ukrainian law, in order to initiate a special pre-trial investigation or special court proceedings against a fugitive, he must be declared in the international searching. But Interpol sometimes refuses to declare certain individuals internationally wanted, citing signs of political persecution. The courts, in their turn, link the declaring in the international searching to the time when Interpol issues a "red card" and, as a result, refuse to grant motions for special pre-trial investigation.

The law signed by the President changes the approach and defines two grounds for conducting a special pre-trial investigation or special court proceedings:

1) if the suspect is declared in international searching;

2) if the suspect unreasonably evades appearing at the summons of an investigator, prosecutor, investigating judge or court (provided he is duly notified of such summons) and is in the territory of the aggressor state or in the temporarily occupied territories of Ukraine.

The investigating judge may arrest such a suspect in absentia.

The document also defines the list of norms of the Criminal Code of Ukraine, according to which a special pre-trial investigation can be carried out. Trial of defendants in such criminal proceedings may be conducted in their absence (in absentia). Exceptions are minors. 
The Law also introduces mandatory publication in the national media and on the official website of the Office of the Prosecutor General of Ukraine of the information on suspects who have been the subject of a special pre-trial investigation, no later than 24 hours after receiving the relevant court decision.

If after the commencement of special court proceedings, the accused person appeared or was brought to court, from that moment the trial continues according to the general rules of the Criminal Procedure Code of Ukraine.

In particular, Law № 1422-IX amends Art. 281 of the Criminal Procedure Code of Ukraine, which defines two grounds for declaring a searching of a suspect: if his/her whereabouts are unknown, and if the suspect evades appearing at the summons of the investigator, prosecutor, investigating judge or court, provided he/she is duly notified of such summons and if there are reasonable grounds to believe that he/she left and/or is in another country or in the temporarily occupied territories of Ukraine.

The adopted amendments to the Criminal Procedure Code of Ukraine stipulate that in case of choosing a measure of restraint in the form of detention of a suspect or accused in case of a search warrant, the validity of the decision is not specified and the amount of bail is not determined.

Earlier, Prosecutor General of Ukraine Iryna Venediktova informed that the adoption of the aforementioned Law, among other things, will allow to send to court 8 thousand cases against deserters, investigation against whom is temporarily suspended. Among the defendants are Ukrainian servicemen who did not leave the peninsula after Russia's occupation of Crimea, as well as servicemen who did not leave the temporarily occupied territories of Donetsk and Luhansk regions (Hlava derzhavy..., 2021).

\section{Conclusions}

In conclusion, we would like to note that almost all democratic states of the world have introduced the institution of proceedings in absentia in their legal system, which, as practice shows, is actively used. This is confirmed by a number of high-profile criminal cases resolved without a defendant (accused). In particular, Crosby against the United States, Jashari against Yugoslavia, Boere against Germany, Degrell against Spain, Diaz against the United States, Factor against Great Britain, Luster against the United States.

Domestic legislation envisages the fulfillment of certain conditions under which a special pre-trial investigation of criminal offenses may be carried out, namely the mandatory participation of a defense counsel, who is involved in accordance with paragraph 8 of Part 2 of Art. 52 of the Criminal Procedure Code of Ukraine, - from the moment of adoption of the relevant procedural decision (decision of the investigating judge on special pre-trial investigation of criminal proceedings) and duly filed motion of the investigator (agreed with the prosecutor) or prosecutor about such proceedings applied to the investigating judge (Article $297^{2}$ Criminal Procedure Code of Ukraine).

Thus, the prosecutor plays a key role in conducting a special pre-trial investigation, which is manifested in the following aspects: initiating a special pre-trial investigation (by appealing to the investigating judge with a motion or approving the investigator's motion); procedural management of such a pre-trial investigation (which imposes additional obligations on the prosecutor to ensure the rights of the suspect, in particular to protect and inform about the progress of the pre-trial investigation); decision-making on the termination of the special 
pre-trial investigation (it is envisaged that the prosecutor is to send to the court together with the indictment a motion to carry out special proceedings against the accused).

We hope that the adoption of the practice of foreign countries and the introduction of changes and additions to existing legislation will help to improve the practical implementation of this institution in our country.

\section{References}

Hlava derzhavy pidpysav zakon pro vdoskonalennya zdiysnennya spetsial'noho dosudovoho rozsliduvannya. (2021). [The President signed a law on improving the implementation of a special pre-trial investigation]. // Access mode: https://www.president.gov.ua/news/glava-derzhavi-pidpisav-zakon-pro-vdoskonalennya-zdijsnennya-68389.

Lapkin A. (2013). Problemy vzaiemodiyi prokurora $i$ slidchoho suddi u kryminalnomu provadzhenni [Problems of interaction between the prosecutor and the investigating judge in criminal proceedings]. Visnyk Luhanskoho derzhavnoho universytetu vnutrishnikh sprav imeni E. O. Didorenka. Luhansk. Issue 2 (63). Pages: 255-265.

Lapkin A. (2018). Prokuror u spetsialnomu dosudovomu rozsliduvanni (in absentia) [Prosecutor in a special pre-trial investigation (in absentia)]. Sumy: Legal horizons. [Правовi горизонти]. Pages: 107-111.

Trofymenko $V$. (2012). Protsesualna forma: sutnist i znachennia u kryminalnomu sudochynstvi [Procedural form: essence and significance in criminal proceedings]. Problemy zakonnosti: akademichnyy zbirnyk naukovykh prats. Kharkiv: Natsionalnyy universytet «Yurydychna akademiya Ukrayiny imeni Yaroslava Mudroho». Issue 120. Pages: 202-209, page 203. 